\title{
A Review and Prospect on the Internationalization Process of Service Multinational Corporations
}

\author{
Liwen Wang, Haiquan Chen \\ School of Management, Jinan University, Guangzhou, China \\ Email: wlw0904@163.com
}

Received 18 January 2015; accepted 3 February 2015; published 5 February 2015

Copyright (C) 2015 by authors and Scientific Research Publishing Inc.

This work is licensed under the Creative Commons Attribution International License (CC BY). http://creativecommons.org/licenses/by/4.0/

(c) (7) Open Access

\begin{abstract}
The internationalization of service industry, which is the main symbol of economic globalization, has entered a new era. As the practice pioneer of service industry internationalization, service multinational enterprises have deeply changed the development pattern of the world service industry, and impacted on the status and interests of the world industry chain. This study takes a systematic review about the internationalization process of service multinational corporations. This internationalization process consists of two portions, the process of service multinational corporations enter the international market and the operation process after entry. Then this study points out the future research prospect, in order to provide a research direction for extending the theory of internationalization process of multinational corporations.
\end{abstract}

\section{Keywords}

Service Multinational Corporation, Internationalization, Market Entry Process, Operation Process

\section{Introduction}

Under the background of international economic rapid development and industrial restructuring, the global industrial structure is changing from "industrial type" to "service type", resulting in a rapid rise of services and promoting the internationalization process of service industry. With the fast development of service industry globalization, new industrial phenomenon cannot be fully explained by the traditional theory. One reason is that the focus of traditional theory is concerned with manufacturing industry, for most research on services by means of the framework of manufacturing industry theory; the other reason is that the service multinational corporations (MNCs) have developed their unique characteristics in the changing business environment, which are dis- 
tinctive from those of traditional industry. Therefore, numerous researchers attempted to extend the theory of service MNCs through both conceptual and empirical study.

Because of the differences in research perspective and focus areas, the research contents of different scholars are not similar. To sum up, they mainly explored service multinational corporation internationalization from the service industry, trade and other macrolevel, or concentrated on analyzing a certain stage of service multinational corporation internationalization. But research on the whole evolution process of service multinational corporation internationalization has not formed a coherent system. In order to construct a comprehensive framework, we started this paper by reviewing two aspects of the internationalization process of service multinational corporations - the process of entering the global market and the operation process after entering into the global market, and then we put forward the trends for future study.

\section{The Procedure of Service MNCs Enter the International Market}

Economic globalization and the rapid development of the world economy have greatly increased the chance of service companies to enter overseas markets; international expansion of the service industry has become an important trend in recent years. The latest research shows that the process of service multinational corporations and manufacturing multinational corporations to enter the international market exhibited the characteristics are not the same [1]-[3]. The traditional theory cannot well explain the entry motives, entry mode choice and the entry order of service multinational corporations enter the international market, so scholars gradually began to launch new studies for service multinational corporations.

\subsection{The Motivation of Service MNCs Enter the International Market}

Prior research suggested that the service enterprises and manufacturing enterprises had similar internationalization motives, including seeking economies of scale and scope, increasing market power, gaining knowledge enhancements, leading to stronger capabilities and innovation, and exploiting entrepreneurial opportunities etc. [4]. However, in the interpretation of specific service industry to enter the international market, these theories do not have universal. Aharoni and Nachum (2000) held that the service multinational companies enter the international market with four motives: First, to follow their customers manufacturing multinational corporations' international expansion into the overseas market; second, the competition advantage of some enterprises in the service industry constantly improve, in order to make full use of these advantages into the foreign market; third, the change of host government policy and service markets achieve liberalization, which reducing market entry barriers; fourth, technological progress improves the degree of service trade [5]. Hitt et al. (2006) further elaborated service enterprises internationalization motives from the perspective of the resource based theory. They found the resources advantage help to promote the service multinational corporations to enter the international market, and examined the importance of two firm resources: human capital and relational capital. The results show that human and relational capital generally had a positive effect on the internationalization process of service multinational corporations [6].

Most studies on the motivation of service multinational corporations enter the international market is based on the perspective of internal motivation and external motivation. Xue Qiuzhi and Zheng Qinqin (2002) analyzed the reason of service multinational corporations' expansion from five aspects, including demand pull, supply push, competition in services, lower entry barriers and to win the trust as well as global studies, and pointed out the internationalization motivation of service multinational corporations not only related to the external environmental conditions, but also to the own development of service sector companies [7]. Liu Minghua (2007) also did a similar study, argued that service multinational corporations' expansion motivation including promoting by the upgrading of national industrial structure, service demand pull, service supply push, technological progress promote, services tradability and lower entry barriers as well as multinational corporations need their own development [8]. Zhang Xiao and Qian Haiyan (2012) through theoretical deduction found that entrepreneurial orientation and social capital, as internal and external motivation respectively, facilitate the globalization of service industry enterprises. These pushing forces take effect dependent on a number of situational factors, including organizational flexibility, human capital and service-product characteristics [9].

As can be seen, the above research mainly from two aspects of internal and external causes to overview the internationalization motivation of service multinational corporations. However, these studies only listed and explained the internal and external factors, but disregard the link of the internal and external causes. In fact, for 
any service multinational corporations to enter the international market not only driven by their own competitive advantage, but also attracted by the different advantages of outside world, and impacted by the interaction between internal and external motivations.

\subsection{The Entry Mode Choice of Service MNCs Enter the International Market}

For a company wishing to enter the international market, entry mode choice is a crucial strategic decision for the future commercial success. The initial entry mode choice would significant impact on the company's future performance and long-term development. Previous theoretical research about entry mode choices are more concentrated on the manufacturing industry. According to the disparities between manufacturing and service firms' international entry mode choice, Keith and Lance (2003) on the basis of transaction cost economics studies, showed three general attributes of transactions that influence transaction cost perceptions: asset specificity, environmental uncertainty and behavior uncertainty, and analyzed different transaction costs, risk propensity, trust propensity how to affect entry mode choice. They found that the investment intensive nature of manufacturing, environmental uncertainties and risk propensity influence the entry mode choices of manufacturers; while behavior uncertainties, trust propensity and asset specificity influence service firms' entry mode choices. Specifically, when the target market exists high level behavior uncertainty, service companies tend to use the joint venture entry mode; service companies with higher specific asset investment tend to use wholly-owned entry mode (in order to reduce the opportunism and disseminate competitive advantage); service companies enter the market with high uncertainty also tend to use the joint venture entry mode [1].

Peinado et al. (2007) had more thorough research on service multinational corporations' entry mode choice from the perspective of transaction cost analysis and organizational capacity. They mainly investigated how a firm's international strategy affects the entry mode choice in the service sector, and found that determinants of entry mode choice which are traditionally analyzed in manufacturing firms cannot be directly transferred to all types of service firms. Some variables often used in manufacturing studies are not significant or exhibit different results. On the basis of empirical research, their research results show that entry mode choice is not just relate to the strategic variable in the manufacturing industry theory, including cultural distance, host country risk, tacit knowledge and international experience, but additional strategic variables also play an important role, such as market seeking motivation and trend following motivation, develop and seek assets, service type etc. Through comprehensive analysis of these strategic variables, various entry modes are available to service multinational corporations, from full-control modes (such as greenfield investment or acquired wholly owned subsidiaries) to shared-control modes (such as partial acquisitions and joint ventures) [3].

The above study is limited to interpret service multinational companies how to select entry mode between full-control modes and shared-control modes, but lack of explaining how to choose different degree decentralization control mode. In order to reflect the various levels of shared-control modes selection, Peinado and Barber (2006) classified services into two groups: capital intensive services and knowledge intensive services, then discussed how the uncertainties influence the choice of entry mode. The main types of uncertainties include uncertainty of host country, uncertainty of demand, and uncertainty of behavior. By these uncertainties combined affect the control level and the resource commitment level when service firms enter the overseas market, and then determine the service enterprises to choose specifically entry mode. With the increase of environmental uncertainty, the study highlighted knowledge intensive service firms prefer to use higher control and resource commitment level entry modes than capital intensive service firms, such as a wholly owned subsidiary; capital intensive service firms in the face of high demand uncertainty, would employ flexible entry modes, which permit quick responses to technological changes, such as management contracts [2].

Different scholars explored entry mode choice of service multinational corporation internationalization from different angle of view, mainly focused on analyzing the influence factors of entry mode choice. But how to affect the choice of entry mode by these factors were less considered, and detailed analysis the specific entry mode even less involved. Cai Xing (2006) attempted to develop an analytic frame for the entry mode of the service multinationals on the basis of the Buckley P and Casson M model [10]. However, this research was limited to theoretical deduction and inference, but lack of empirical proof.

\subsection{The Entry Order of Service MNCs Enter the International Market}

For the manufacturing industry multinational corporations, early entrants into new market often enjoy firstmover advantages (FMAs), including learning or experience curve effects, the preemption of scarce input fac- 
tors, the selection of favorable geographic locations, and the increase of buyer switching costs. Early entrants use FMAs will get better market performance versus later entrants. The early theory generally accepted that to be market pioneers is not important for service multinational companies [11]. But Peter et al. (2009) came to a different conclusion under the analysis framework of resource advantage theory: service enterprises enter the international market also enjoy a first-mover advantage [12]. There is a significant relationship between entry order and firm performance. Early entrants not only preferentially occupy the best local resources, especially human resources, but also develop the relationship, information and organizational resources advantage, then contributing to establish long-term customer relationship, to create the organizational structure and culture, and to achieve sustainable competitive advantage.

Although service multinational corporations become the forerunners in the internationalization process will bring many advantages, but some companies are more willing to enter the market has been occupied. By imitating competitors, the later entrants can reduce risk and improve efficiency, increase the chance of surviving, and further reduce the gap between the forerunners. Wu Xiaoyun and Li Hui (2012) made use of the new institutional theory, organizational learning theory and the resource based view to explain the imitative behavior of service multinational corporations get into the overseas market. Their studies showed that three form of imitation: frequency-based imitation, trait-based imitation and outcome-based imitation. Service multinational corporations would mimic the three behaviors in response to the uncertainty of external environment, the uncertainty of the result of specific behavior and the uncertainty of resource selection [13]. In addition, the later entrants' international experience, firm size, subsidiary ownership structure, and economic development rate of the host country can mitigate late-mover disadvantages [12].

Existing research on analyzing the entry order of service multinational corporations to enter the international market focuses on the first-mover advantage and backward advantage, but neglected to consider the relevant disadvantage. In fact, the internationalization process of service multinationals specific choice first entry or after the first entry should consider its own characteristics, industry characteristics and environment characteristics.

\section{The Operation Process after Service MNCs Enter the International Market}

In addition to studying service multinational corporations enter the international market, scholars also pay attention to these research issues, which associated with service multinational companies how to operate in the host country after entry. For example, service multinational corporations how to adapt the host country's business environment, how to form and implement strategies compatible with the environment for survival and development, how to establish competitive advantage in the host country and so on. Scholars study the operation process after service multinational corporations enter the international market, mainly based on the following three aspects: adapt to the host environment, establish the competitive advantage through the formulation and implementation of strategies, and explore cross-border operations performance.

\subsection{Adapt to the Business Environment}

In the host country, the operation process of service multinational corporations includes four stages: learning phase, opportunistic phase, re-internationalization phase, and maturation phase [14]. Among them, the first two stages are the adaptation environment process of service multinational corporations. Services MNCs enter the international market will face different operating environment from the domestic market. Deepak and Stephen (2002) studied the service MNCs how to handle different international business environment, and presented multinational companies' development is a process from encounter setback to establish competitive advantage, then to improve the business performance, including adapt to the complex and unstable host environment. They also proposed an integrated model to analyze the interaction between service multinational corporations and international business environment, the model reflects service multinational firms establish their competitive advantage should base on the interaction with the dynamic environment [15].

International market environment is complex for service multinationals. Most service multinationals enter the international market will face similar challenges: relatively smaller market share, limited resources and the low ranking etc. Moreover, the government policy in some countries makes the business environment more dynamic [14]. In addition to the host country government policy, the environmental factors in the expansion of the service multinationals also include the company's specific location. Sumit et al. (2008) showed that compare the ownership of a subsidiary, the particular location has greater impact on service multinationals international, because 
the specific location advantages bring benefits would be more obvious than the former [16]. For instance, the local talent pool serves the local demand initially, but as the ability talents aggregation, foreign direct investment into the region will be considered, service multinational corporations will also consider expansion in this region, the purpose is to reduce the high quality human resources search costs [17].

In addition to accommodate the host country's business environment, the international operation of service industry multinationals should consider the impact of the host country government policies, location and other factors. Only to meet the changes of market environment, services MNCs could establish and implement targeted strategies, then form their own unique competitive advantage.

\subsection{Establish the Competitive Advantage}

Competitive advantage of an enterprise can bring more profit or benefit than other companies. Gaining the competitive advantage depends on the implementation of the competition strategy. While in the establishment of core competitive advantage, service multinational corporations first consideration is the sequence of investment strategy, namely decide to invest what kind of business: invest the core business or invest the non-core businesses. Hiromu (2010) studied the characteristics of service multinationals, and pointed out service industry multinationals to carry out related activities closely linked to the parent company's core strengths or not, which is determined by the dynamic environment of the host country [18]. On the basis of business relations and regional characteristics, Anthony and Shige (2007) proposed investment classification method, through empirical research on the Japanese trading companies found early investment of service MNCs closely related to their core business, rarely consider the non-core business associated with regional characteristics. The reason is that invest the core business can be better use the accumulation of the parent company's competitive advantages. However, with the accumulation of local knowledge, service multinational corporations would choose more region characteristics business [19].

In addition, service MNCs still exist "home-based" phenomenon. Namely, the home country's income accounts for the majority of total revenue. The fact has attracted scholars to focus on the regional strategy and global strategy. Alan and Alain (2008) compared the service industry and the manufacturing industry multinational corporations, found that "home-based" phenomenon of service multinational corporations more obviously than manufacturing industry multinational corporations. Most service multinationals select regional strategy rather than global strategy. The reason for this relative lack of globalization is that it is difficult to control the upstream and downstream sectors of the value chain and to pick the local standard supply under the height difference of the host environment [20].

What factors need to be considered when service multinational corporations in the expansion of the international market to establish their own competitive advantage? Combined international business theory and economic geography theory, Patrik and Evelina (2010) emphasized the importance of people and place, shifting pace, complex networks of production, and new balances of power together lead to establishing service multinational corporations' competitive advantage [21].

Therefore, in the process of forming its own competitive advantage, service multinational corporations should adjust the strategy in a dynamic perspective when the environment changes. Only on the basis of dynamic environment to establish competitive advantage, it may be permanently owned by service multinationals, and obtain a high level of performance in the international market.

\subsection{Discussion on Business Performance}

Strategic choices will affect the business performance of service multinational corporations, such as in the sequential investment strategy, the initial selection of international investment in the core business will acquire investment performance better than those of non-core business [19]. However, research about the operating performance of service MNCs, scholars are more concerned about the relationship between the degree of internationalization (multinationality) and performance.

Early research on the relationship between international level and performance of the manufacturing MNCs has proposed the linear relationship model, the inverted J-shaped curvilinear relationship model and the inverted U-shaped curvilinear relationship model. But Capar and Kotabe (2003) found that a U-shaped relationship exist between multinationality and performance of service multinational corporations.In other words, at lower levels of multinationality, international diversification would reduce performance up to a certain point owing to dis- 
economies of scale associated with such expansion; at higher levels of multinationality, performance begins to increase, probably owing to the benefits of economies of scope more than diseconomies of scale [22].

Farok et al. (2003) showed that both a U-shaped relationship and an inverted U-shaped between the multinationality and performance of service multinational corporations, so they combined the two to propose a new unified three-stage theory of international expansion (S-shaped curve) [23]. The main content of the three-stage theory is that service multination companies are not familiar with the international market at the initial stage of internationalization, and there are a variety of barriers to entry, so the establishment of market and the acquisition of knowledge must pay greater cost, at this time the performance of enterprises is declining; With the in-depth process of internationalization, service multinationals could more effectively seek resources, access to lower-cost raw materials, and the effect of scale economy gradually reflect, the subsidiaries knowledge shift ability gradually improve, a series of business advantages gradually appear, so as to increase the performance; When the degree of internationalization exceeds the optimal level, service multinational corporations carry on to external expansion will spend the costs surpass the profits, increase the complexity of the international operation at the same time, and also increase the cooperation and governance costs, the excessive expansion will damage the performance of enterprises.

The current state of research shows that the S-shaped relationship between international level and firm performance is a trend and hotspot in this field, more and more scholars use this model to confirmatory analysis. Farok et al. (2007) used the model to analyze the situation of service sector multinationals operation in the emerging economic market, the results showed that companies access to emerging market only occupy the first two stages in the three stage of the model, the whole is in a U-shape structure, which may be related to emerging economy with a huge market potential [24]. Dina (2012) verified the presence of S-shaped structure also among knowledge intensive service companies and capital intensive service companies, and the former obtain financial performance to be faster than the latter [25].

\section{Conclusions and Prospects}

The internationalization process of service MNCs includes two stages: the process of entering global market and the operation process after entry. Market entry process mainly studies in terms of entry motivation, entry mode choice, entry order; operation process mainly analyzes from business environment, business strategy, business performance. Although the service multinational corporation theory are getting more attention than the manufacturing multinational corporation theory, further explorations (e.g. theory extension, instructions for practice) are needed to enrich the service industry internationalization research [26]. From the recent literature, research on the international process of service MNCs shows the following trends:

First, pay attention to the heterogeneity of the service industry and break through the bondage of traditional theory, deepen the study of the process of service multinational corporations enter the international market and the operation process after entry. Due to the two processes covers widely, scholars prefer to study one process or a part of the two processes. For example, researchers focus on the ownership and location selection in the entry process, or focus on service outsourcing in the business operation process.

Second, research on service multinational corporations in the emerging market began to increase. Services MNCs originated and developed in developed countries. Based on this background, it's difficult to explain the service MNCs internationalization behavior in the emerging market, which makes theorists have a keen interest in the law of its development, and try to find a breakthrough from the emerging market characteristics. Along with the rapid development of these countries and regions, and the service market being more open, Scholars discuss the internationalization process of service MNCs in the emerging market countries gradually warming.

Third, manufacturing and producer services become integration and development. In the past few years, the service business in multinational manufacturing industry has become an important growth point. Producer service industry is directly related to the manufacturing industry, which independently develops from the producer service sector of manufacturing. At present, most of the manufacturing companies are facing fierce competition in the traditional market, and now they are shifting their focus to the global service operation. Manufacturing firms need to deal with more and more low profit margins by expanding services business to obtain compensation. In some industries, in order to increase market share, products are sold even at the cost level, but from their services to increase revenue and profit rate. Thus, the integration and development of manufacturing and producer service will be a hot trend with the manufacturing firms to change their business model. 


\section{Acknowledgements}

The paper is financially supported by humanities and social science project of ministry of education of China "theoretical and empirical study of formation of modern wholesale distribution organization and cultivation of emerging middle circulation business” (NO: 11YJAZH009), and by humanities and social science key project of Guangdong "institutional space and path selection to promote the development of modern service industry in Guangdong province” (NO: 2012ZGXM_0004).

\section{References}

[1] Brouthers, K.D. and Brouthers, L.E. (2003) Why Service and Manufacturing Entry Mode Choices Differ: The Influence of Transaction Cost Factors, Risk and Trust. Journal of Management Studies, 40, 1179-1204. http://dx.doi.org/10.1111/1467-6486.00376

[2] Sanchez-Peinado, E. and Pla-Barber, J. (2006) A Multidimensional Concept of Uncertainty and Its Influence on the Entry Mode Choice: An Empirical Analysis in the Service Sector. International Business Review, 15, 215-232. http://dx.doi.org/10.1016/j.ibusrev.2006.02.002

[3] Sanchez-Peinado, E., Pla-Barber, J. and Hébert, L. (2007) Strategic Variables That Influence Entry Mode Choice in Service Firms. Journal of International Marketing, 15, 67-91. http://dx.doi.org/10.1509/jimk.15.1.067

[4] Beamish, P.W. and Lu, J.W. (2001) The Internationalization and Performance of SMEs. Strategic Management Journal, 22, 565-586. http://dx.doi.org/10.1002/smj.184

[5] Aharoni, Y. and Nachum, L. (2000) Globalization of Services: Some Implications for Theory and Practice. Routledge, Oxford.

[6] Hitt, M.A., Blierman, L., Uhlenbruck, K., et al. (2006) The Importance of Resources in the Internationalization of Professional Service Firms: The Good, the Bad, and the Ugly. Academy of Management Journal, 49, 1137-1157. http://dx.doi.org/10.5465/AMJ.2006.23478217

[7] Xue, Q.Z. and Zheng, Q.Q. (2002) The Emergence and Expansion Motivation of Service Multinational Corporation. World Economy Study, 5, 52-57.

[8] Liu, M.H. (2007) Global Expansion of Service Transnational Corporations: Motivation and Route Choosing. International Economics and Trade Research, 11, 34-38.

[9] Zhang, X. and Qian, H.Y. (2012) The Global Expansion of Service Sectors and Its Effect: A Factor Study. Journal of Nanjing University, 4, 60-67.

[10] Cai, X. (2006) On the Entry Mode of the Services Multinationals. Journal of Shanghai Business School, 7, 22-26.

[11] Song, M.X., Di Benedetto, C.A. and Zhao, Y.L. (1999) Pioneering Advantages in Manufacturing and Service Industries: Empirical Evidence from Nine Countries. Strategic Management Journal, 20, 811-835. http://dx.doi.org/10.1002/(SICI)1097-0266(199909)20:9<811::AID-SMJ52>3.0.CO;2-\#

[12] Magnusson, P., Westjohn, S.A. and Boggs, D.J. (2009) Order-of-Entry Effects for Service Firms in Developing Markets: An Examination of Multinational Advertising Agencies. Journal of International Marketing, 17, 23-41. http://dx.doi.org/10.1509/jimk.17.2.23

[13] Wu, X.Y. and Li, H. (2012) Influencing Factors on Imitation Behavior of Internationalization of Service Multinational Corporation. Proceedings of the International Joint Conference on Service Sciences, Shanghai, 24-26 May 2012, 266269.

[14] Laanti, R., McDougall, F. and Baume, G. (2009) How Well Do Traditional Theories Explain the Internationalisation of Service MNEs from Small and Open Economies?-Case: National Telecommunication Companies. Management International Review, 49, 121-144. http://dx.doi.org/10.1007/s11575-008-0128-3

[15] Sethi, D. and Guisinger, S. (2002) Liability of Foreignness to Competitive Advantage: How Multinational Enterprises Cope with the International Business Environment. Journal of International Management, 8, 223-240. http://dx.doi.org/10.1016/S1075-4253(02)00067-4

[16] Kundu, S.K. and Merchant, H. (2008) Service Multinationals: Their Past, Present, and Future. Management International Review, 48, 371-377. http://dx.doi.org/10.1007/s11575-008-0021-0

[17] Manning, S., Ricart, J.E., Rique, M.S.R. and Lewin, A.Y. (2010) From Blind Spots to Hotspots: How Knowledge Services Clusters Develop and Attract Foreign Investment. Journal of International Management, 16, 369-382. http://dx.doi.org/10.1016/j.intman.2010.09.007

[18] Inoue, H. (2009) Several Characteristics of Service Multinational Corporations. Centre for International Business Studies, $1-31$.

[19] Goerzen, A. and Makino, S. (2007) Multinational Corporation Internationalization in the Service Sector: A Study of 
Japanese Trading Companies. Journal of International Business Studies, 38, 1149-1169. http://dx.doi.org/10.1057/palgrave.jibs.8400310

[20] Rugman, A.M. and Verbeke, A. (2008) A New Perspective on the Regional and Global Strategies of Multinational Services Firms. Management International Review, 48, 397-411. http://dx.doi.org/10.1007/s11575-008-0023-y

[21] Strom, P. and Wahlqvist, E. (2010) Regional and Firm Competitiveness in the Service-Based Economy: Combining Economic Geography and International Business Theory. Journal of Economic and Social Geography, 101, $287-304$.

[22] Capar, N. and Kotabe, M. (2003) The Relationship between International Diversification and Performance in Service Firms. Journal of International Business Studies, 34, 345-355. http://dx.doi.org/10.1057/palgrave.jibs.8400036

[23] Contractor, F.J., Kundu, S.K. and Hsu, C.-C. (2003) A Three-Stage Theory of International Expansion: The Link between Multinationality and Performance in the Service Sector. Journal of International Business Studies, 34, 5-18. http://dx.doi.org/10.1057/palgrave.jibs.8400003

[24] Contractor, F.J., Kumar, V. and Kundu, S.K. (2007) Nature of the Relationship between International Expansion and Performance: The Case of Emerging Market Firms. Journal of World Business, 42, 401-417. http://dx.doi.org/10.1016/j.jwb.2007.06.003

[25] Abdelzaher, D.M. (2012) The Impact of Professional Service Firms' Expansion Challenges on Internationalization Processes and Performance. The Service Industries Journal, 32, 1721-1738. http://dx.doi.org/10.1080/02642069.2012.665901

[26] Javalgi, R.G. and Martin, C.L. (2007) Internationalization of Services: Identifying the Building-Blocks for Future Research. Journal of Services Marketing, 21, 391-397. http://dx.doi.org/10.1108/08876040710818886 
Scientific Research Publishing (SCIRP) is one of the largest Open Access journal publishers. It is currently publishing more than 200 open access, online, peer-reviewed journals covering a wide range of academic disciplines. SCIRP serves the worldwide academic communities and contributes to the progress and application of science with its publication.

Other selected journals from SCIRP are listed as below. Submit your manuscript to us via either submit@scirp.org or Online Submission Portal.
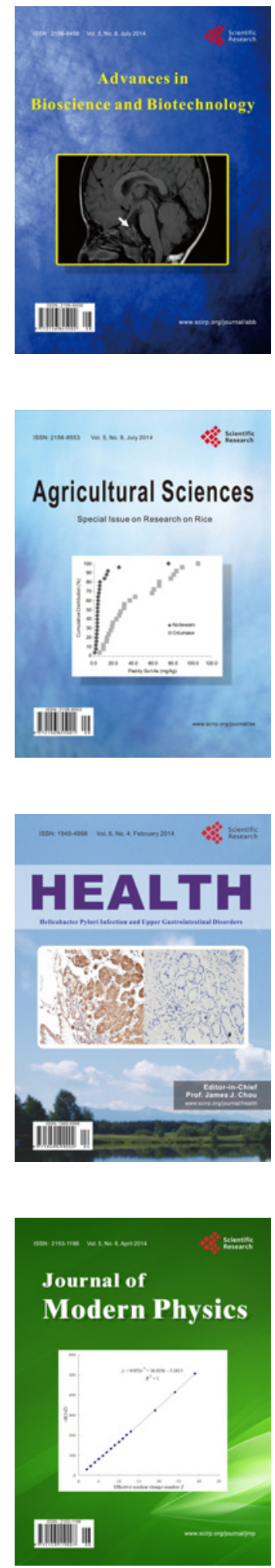
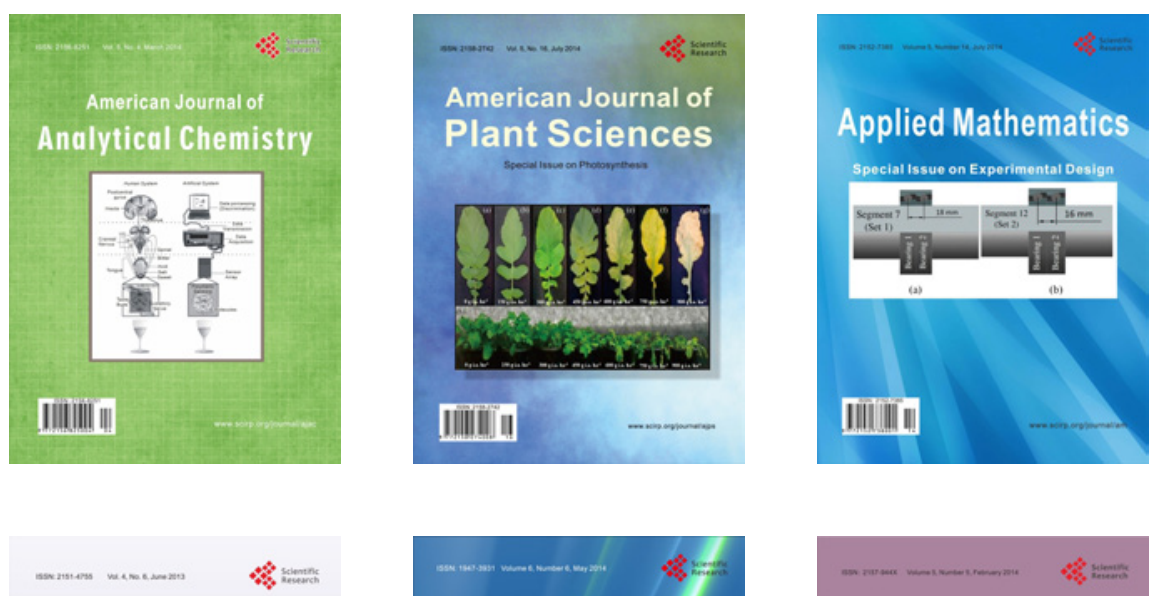

Creative Education
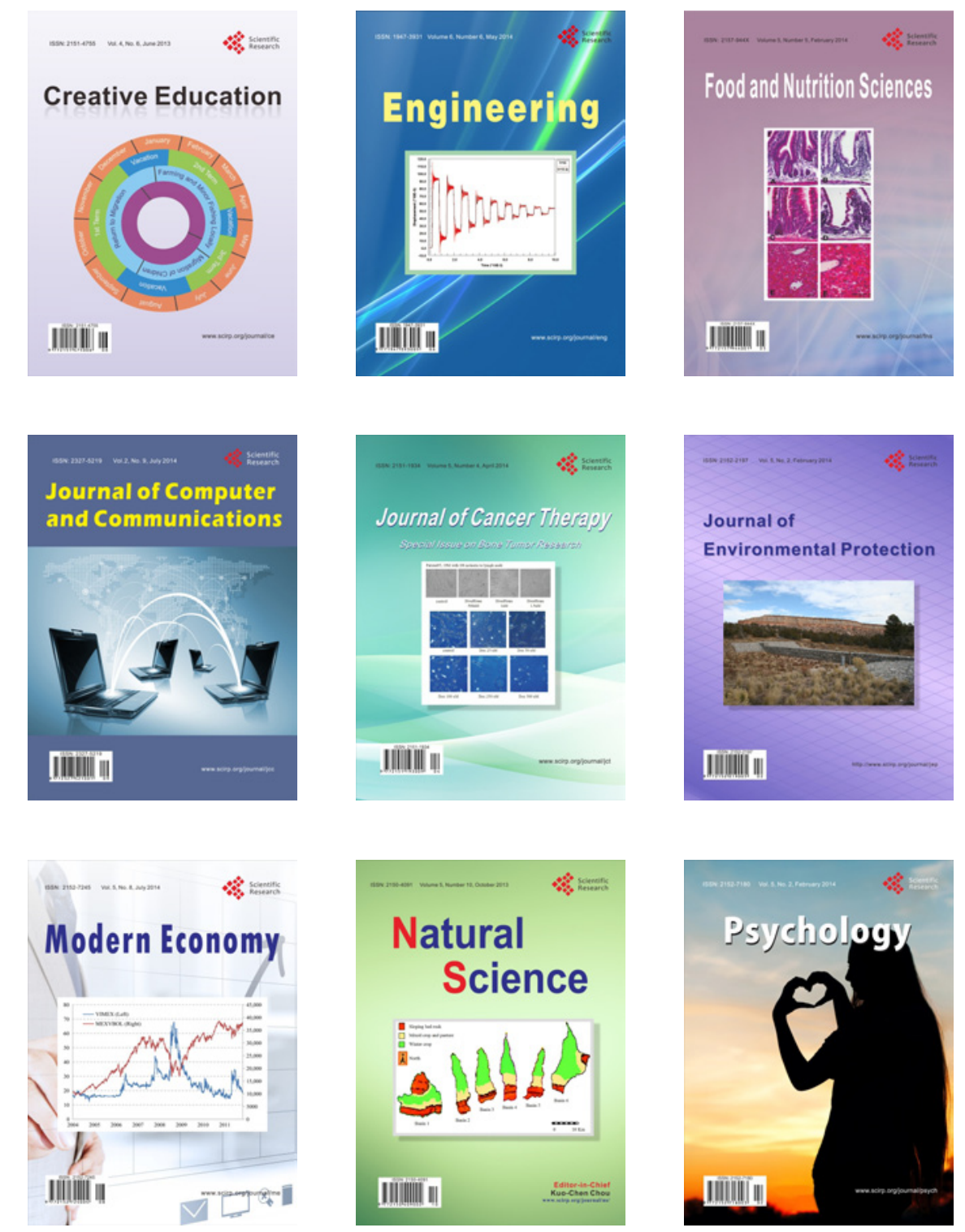